\title{
Role of Islamic Microfinance in Alleviating Poverty in Bangladesh: A Study on RDS of IBBL
}

\author{
Md. Masud Parvej ${ }^{1}$, Md. Asad Iqbal Chowdhury ${ }^{2}$, Md. Kazi Golam Azam ${ }^{2}$, Md. Musharof Hossain ${ }^{2}$ \& Abdullah \\ Mohammad Ahshanul Mamun ${ }^{2}$ \\ ${ }^{1}$ Southeast Bank Limited, Bangladesh \\ ${ }^{2}$ International Islamic University Chittagong, Bangladesh \\ Correspondence: Md. Asad Iqbal Chowdhury, International Islamic University Chittagong, Bangladesh.
}

Received: March 2, 2020

doi:10.5430/ijfr.v11n4p111

\begin{abstract}
The goal of this study is to determine the role of Islamic microfinance in alleviating poverty, a study on RDS (Rural Development Scheme) of the Islamic Bank Bangladesh Limited. The study employed interview method, descriptive statistics, T-test, Chi-squared test, and multiple regression analysis to investigate a total of 328 samples (RDS borrowers). The sample has been purposefully selected for the study from two districts of Rajshahi division of Bangladesh. The results of our study indicate that in any category having an income level of more than 5001 to 10000 , after access to the RDS scheme of IBBL, overall, $72 \%$ of respondent's income increased. In the case of impact analysis of the program on poverty alleviation, the results of the statistical analysis (regression model) revealed that there is a significant impact of the Rural Development Scheme (RDS) on poverty alleviation (P-value-0.000).
\end{abstract}

Keywords: RDS, Islamic microfinance, Bangladesh, poverty

\section{Introduction}

Bangladesh, mainly an agriculture depending country, has about $17.22 \%$ of the entire Gross Domestic Product (GDP) of the country derived from agriculture as well as accommodates around $45.6 \%$ of the labor force (Statistics, 2015). The GDP boom in the country depends mainly on agriculture. However, natural calamities like cyclones, floods, and drought, loss of manufacturing in both meals and cash crops as a normal phenomenon impede its standard performance. Although these natural and man-made challenges, there has been an impressive growth in food grain production in the latest years due to the use of current agricultural machinery, equipment, and the generation has increased. The fundamental vegetation of Bangladesh is rice, jute, sugarcane, potato, pulses, wheat, tea, and tobacco, etc. Now a day, Government policy regarding crop diversification program, investment, supply, extension work, research, and input distribution is yielding fantastic results. The country is now on the threshold of reaching self-sufficiency in meals grain production.

The fifth decennial census, conducted by the Bangladesh Bureau of Statistics on March 15-19,2011exposed a report that the populace (adjustment) of the country stood at 149.77 seventy-seven million in 2011 and out of this population 74.98 million is male, and 74.79 million is female. The growth charge of the population 2011 census became 1.37 according to per annum. The density of the population turned into 843 in step with sq.Km. In 2001which multiplied to 976 in keeping with sq.Km. in 2011.

The male percent is 100.25 , and an assessment with female ratio and around 32.1 million families in the country, allotted over 56,348 mazes (revenue villages) (Statistics, 2015).

The general employed population in the country has been projected as 58.1 million as in step with the Report of Labor Force Survey, 2013, of which 41.2 million are male, and 16.8million are woman while it changed into 54.1million for each gender, 37.9 million for male and 16.2million for women within the Labor Force Survey, 2010 as according to ordinary definition (ILO, 2016).

This look at especially assesses the position of interest-free microfinance in rural development of Bangladesh through interest-free microfinance. According to Household Survey 2010, the charge of poverty varies from vicinity to region. The principal goal of the examiner is to evaluate the role of RDS, a microfinance program of Islamic Bank 
Bangladesh Limited, in alleviating poverty. To accomplish the main goal, the following precise objectives have been covered in the study:

a) To examine the poverty situation of Bangladesh and Organizations involved in intervening poverty.

b) To examine the impact of the Rural Development Scheme (RDS) of Islami Bank Bangladesh on poverty alleviation and household income before and after the adoption of microfinance investment.

Following hypotheses have been developed against the objective set forth as above:

H1: Rural Development Scheme (RDS) of Islami Bank Bangladesh Limited (IBBL) has a significant impact on poverty alleviation.

H2: Rural Development Scheme (RDS) of Islami Bank Bangladesh Limited (IBBL) has a significant impact on household income before and after the adoption of microfinance investment.

The rest of the elements of this look at is structured as follows: Section 2, in brief, discusses the literature evaluations on microfinance in Bangladesh. Section 3 discusses the contribution of RDS in Bangladesh. Section 4 depicts the methodology used in this research. Section 5 depicts the analysis of the consequences of the impact of RDS on poverty alleviation. Section 6 concludes the studies observe with some hints and avenues for further studies.

\section{Review of Literature}

In the last thirty-year microfinance region of Bangladesh accomplished constant growth. Initially, most effective the conventional microfinance program became available, later the Islamic microfinance gadget additionally emerged. Comparing to conventional microfinance, Islamic microfinance is practicing more ethical to their customers, as substitute earnings maximization (Begum, Alam, Mia Md, Bhuiyan, \& Ghani Ahmad Bashawir, 2019). Rahman (2010) recommended or opined that the application of microfinance program with the increment of size, demand-led practical education in different income-generating activities, and monitoring of more Shariah compliance of the mode in all rural areas of the country. Another study by Halimuzzaman, Khaiar, and Hoque (2014) pronounces that IBBL would possibly face some hassle in either operating system or utilization method of the clients, and it needs to be tested critically. Furthermore, the study suggests an arrangement of proper education centers is needed for better utilization of the RDS fund. Many policymakers and researchers are concentrating on the way to transform and restructure this big zone in accordance with the religious ideals of the large part of the population (Begum et al., 2018).

Several research on traditional microfinance proposes that traditional models are participating in alleviating poverty; however, in the end, sustainable development now not yet achieved. However, the newly evolved Islamic microfinance system displaying its overall performance in lowering poverty as well as ensuring the socio-economic situations in current years (Rashad, 2014). In a different look at Jahur \& Quadir, (2010), RDS indicates a significant influence on profits and income-generating activities of borrowing contributors or members, and growth of overall performance parameters of RDS are robustly checked over the examination period. Jinan, Bashar, Jahan, and Khanam (2008) founded that the household has incredible improvement in the dwelling living standard because of borrowed funds from RDS; however, a good enough size of the investment is important to make investments in income-generating activities properly.

In another study on "Socioeconomic Impact of IBBL Microfinance on Rural Women in a Selected District of Bangladesh" showed that IBBL is serving the most vulnerable section of the society, married ladies from landless and marginal farm families (Jahan \& Mamun-ur-Rashid, 2015). Income from each agriculture and the non-agricultural source has been changed notably after receiving the loan.

Bashar Bhuiyan (2013) elucidates that Islami Bank micro-investment borrowers have better records in better use of borrowed funds in income-generating activities to lessen vulnerability as well as the development of livelihood conditions in assessment with the micro-investment borrower of Grameen Bank.

Another group of scholars opined that a notable number of micro-investment borrowers used their borrowed money in house repairing, children's marriage, and furniture purchase, alternatively make investments in income-generating sources ((Rahman, Jafrullah, \& Islam, 2008)). Therefore, appropriate tracking and supervision are to be conducted at the very inception so that one can ensure proper use of the fund for income-generating activities.

Rahman et al. (2008), in their research, discovered that RDS functioning capably due to better coverage efficiency in villages through branches, center and employee control and creation of micro-enterprise, leading social activities and financing program shaped noteworthy social performance. 
Islam (2016) counseled that decision-maker has to take awareness program on the increment of the extent of the RDS fund as the value of the currency is changed due to inflation and other financial reasons and the Bank may lock more market proportion if they are able to come out with generous guidelines like the choice of the potential borrower as a substitute than a spiritual factor of view.

Bhuiyan, Siwar, Ismail, and Talib (2011) states that ATM's overall performance changed into quite nice in admiration of earning revenue, financial fees, and self-sufficiency.

In contrast, inefficient overall performance was recorded as institutional characteristics outreaches to the poor, and in comparison with RDS, low efficiency of AIM is found out in phrases of operating costs. On the whole, the study suggested that AIM may implement microfinance in the Islamic mode following RDS instruments as Islamic Microfinance has more difficulty in managing sick humans extra closely and aimed to mitigate their socioeconomic desires in a holy way.

Al-Mubarak (2014) showed that "poverty alleviation is slow for considerable reasons such as high interest-bearing investment taken from the conventional MFIs, deprivation from the right of human development, incremental family stress in rural areas because of the excessive women empowerment and most particularly isolation from mounting a balanced life between the spiritual and material aspects."

Ashraf (2010) indicated that some notable elements like membership, income, and living standards, the risk of the loan, membership standards, and spiritual restrictions are not at an exceptional level, which impedes poverty alleviation from microfinance. Alternative measures should be under consideration so that you can alleviate poverty from the root stage of the society, and Islamic microfinance institutions are being proposed as probably the contemporary socio-cultural, religious and household's psychological background of Bangladesh like other Muslims countries within the World.

Abul, Chamhuri, Abdul, and Basri (2011) talked about that poverty is increasing day by day, even in every year in the rural and urban regions dealt with as a central illness that precludes overall development in Bangladesh. Most of the study turned into done that specializes in a descriptive concept of Islamic principles and theories in the micro-funding field. Considering the impact assessment, RDS plays a crucial function in the development of living standards and the socio-economic improvement in the absence of interest. Furthermore, their study states that borrowed fund was used in Productive Income Generating Activities (IGAs), loan repayment performance was satisfactory, and small borrowers repayment history were good followed through the medium and large borrowers.

Riwajanti (2013) argued that the Islamic approach of poverty alleviation has more attention on the moral/religious aspect rather than conventional technique and Islamic microfinance with a unique feature compared to traditional counterpart, gives a probable option to alleviate poverty. The principle of Islamic microfinance aiming is to use Islamic values to encourage social justice for all and constructing human capabilities to make sure continuous financial development. Therefore, the factor of Value and ethical aspect, targeted at the human side and community's accountability, is predicted to be greater productive and comprehensive in poverty alleviation. In practice, it has an interest free approach; hence, it will not drag clients to debt trap and worse condition.

Kustin (2015) in his observe on "Islamic Microfinance: Context, Culture, Promises, Challenges" claims that the modern state of affairs of Islamic microfinance still considers as a scattered industry where there are little experiments and more traditional institutions, as well as less National data source or systematic method of collecting data, is minimal. The review of the present literature suggests that poverty is an unresolved problem for most developing nations, along with Muslim-majority countries like Bangladesh.

In a recent look by Rulindo \& Pramanik, (2013), necessitated that for better capacity building of the Islamic microfinance client, institution needs to adopt spiritual and religious programs in the short run which might also positively influence their clients.

In another recent study Bhuiyan et al., (2011b) have been, there is a universal scarcity of quantitative literature on this field, and maximum research was based totally on a descriptive presentation of Islamic principles \& theories within the micro-funding area. (Jamal \& Sheikh, 2013) found that the improvement of micro-entrepreneurs, using the Shariah complied models, are not available even though Islamic micro-finance establishments aim to make bigger micro-entrepreneurs, and they are solely on a critical stage of analysis. Khan (2008), opined that 'Shariah-compliant' issues are given less significance in microfinance applications even we work in a Muslim environment.

Jinan et al. (2008), in their research on the impact of RDS of IBBL on its beneficiaries in the Mymensingh Sadar area, found that the recipients have a substantial upward trend in their income (61 percent in agriculture and 89 percent in the business industry). According to estimates of Uddin, RDS has a notable positive impact on the fulfillment of the 
client's food intake, education, education, taking clinical treatment, better clothes, the use of the toilet, using clean and pure consuming water, income and expenditure. RDS products are being offered aimed to ensure extra participation of mass human beings who stay below the poverty line, and RDS Scheme is treated as a successful project in economic development (Rahman et al., 2008). Islamic microfinance has sufficient room to flourish because its recognition is growing amongst each Muslim and non- Muslim community of an economy.

Poverty is a vulnerable situation of human life that is connected with a standard of living, in addition to the socioeconomic condition of the population. Though apparently, poverty is specifically connected with money income; however, it has a non-income component also. Sustainable poverty alleviation requires economic growth that enables pro-poor growth. Overall economic growth and development of the country facilitate income generation that also helps a satisfying non-income item. In a developing country, poverty becomes a crucial issue, and poverty alleviation in recent years has been encouraging. Bangladesh is experiencing peak evidence of poverty in South Asia, and it placed in the third position after India and China.

HIES of the Bangladesh Bureau of Statistics [BBS], (2005) states a downward trend in income poverty. According to the cost of basic needs (CBN) method survey, the frequency of debt at the National level declined from 48.9 percentage in 2000 to 40.0 percentage in 2005 , poverty lessen by means of 1.8 percentage between 2000 and 2005 considering percentage points during through preceding decades and hardcore poverty is probably to be declining during the same period.

However, after analyzing the above-stated discussions and feedback at the overview of the preceding and modern researches on the highlighted topics, it can be concluded that most of the research studies were primarily based on the mentioned model regarding microfinance instruments lending strategies, performance, outreach, etc. It is also found that no investigation was observed related to the issues of taking consciousness program to unfold the understanding of interest-free micro-finance among rural people. So far, I studied that no study was also observed concerning the scarcity of Islamic microfinance institutions. It is also observed that traditional microfinance establishments are increasing each day compared to Islamic microfinance institutions. At present, in Bangladesh, poverty is a significant concern of the development plan of the government and cannot combat by the government solely. So, for the sake of alleviating poverty and the development of the rural poor, the above-said difficulty has been treated as a vital concern to both government and non-government policymakers and researchers.

\subsection{Status of Poverty in Bangladesh}

In Bangladesh, in step with capita earnings has positively modified with more than 130 percent and poverty more than half since 1971. Now, Country is probably to obtain foremost movements of the Millennium Development Goals (MDGs) after putting off constraints as a low-income country with adequate poverty, dispossession, and inequality (IFAD).

Almost 45 million inhabitants of Bangladesh, one 1/3 of the general population, live life below extreme poverty and a substantial portion live lifestyles with severe poverty. The poverty rate within the urban region is 28 percentage, but in rural areas, it's36 percent, and plenty of inhabitants face constraints of adequate diet, suffering from scarcity for a long period. Again, about 14 percentage of children are suffering from acute malnutrition and chronically malnourished, respectively (IFAD).

It is predicted that people in urban areas like Sylhet, Dhaka, Chittagong, Rajshahi, and Khulna, enjoying better trendy of dwelling with clean water, gasoline, and electricity amenities. However, a noteworthy part of city households besides this town face issues of dwellings, power, health care, and clean drinking water.

The population estimated as 157.90 million in Bangladesh, reported by using Asian Development Bank in April 2016, out of which about $31.5 \%$ live under the national poverty line. As per record of HIES report, near about 32.03 percent households during last twelve months obtained loans from both financial and non-financial institutions, informal moneylenders and friends of which 21.11 percentage, 18.37percent, 14.29 percent of Grameen Bank, ASA and different NGOs respectively in which 35.08 percentage from rural areas and 23.70 percent from urban vicinity for the purpose of creating Business(23.70\%), followed by Agriculture(21.09\%) (Bangladesh Bureau of Statistics [BBS], 2010). Furthermore, urban poverty appears to be lessening than rural areas as a decrease of debt in the urban area is 1.24 percentage; however, in rural areas, it is 1.13percent (Titumir \& Rahman, 2011).

The deprived population of the world is challenging for the fulfillment of basic/primary needs like food, clothes, health care, education, pure consuming water, and sanitation; however, Bangladesh is facing fundamental contests of poverty and inequality inside its households. Millennium Development Goals (MDGs) made an international commitment to alleviate poverty and hunger by way of fostering global collaboration for improvement by 2015 , 
while vision-2021 of the acting government of Bangladesh committed to removing poverty to 25 percent and 15 percent by way of the year 2013 and 2021 respectively. As the occurrence of poverty in Bangladesh is holding top positions in the world, tormented by hardcore poverty and vision-2021 goes to mature, so it's time to see whether Bangladesh is a success in its vision.

According to HIES report, there is a terrific percent of poverty reduced from the year 2010 to 2016 (Bangladesh Bureau of Statistics [BBS], 2016). Considering the poverty headcount rate, poverty reduced from $31.5 \%$ to $24.3 \%$ according to the top poverty line, and as in keeping with the lower poverty line, the headcount ratio decreased from $17.6 \%$ to $12.9 \%$ from the year 2010 to 2016 . Similarly, the poverty gap as consistent with the higher/upper poverty line reduced $5 \%$ from $6.5 \%$, and as per the lower poverty line, the poverty gap decreased to $2.3 \%$ from $3.1 \%$ between 2010 and 2016.

As per the latest House Income and Expenditure Survey (HIES) by the Bangladesh Bureau of Statistics (BBS), the poverty rate of Bangladesh dropped to $24.3 \%$ in 2016, reflecting a $7.2 \%$ point decline in the last five years (see Table $1)$.

Table 1. Growth trends in rural and urban poverty (In \%) in Bangladesh

\begin{tabular}{llll}
\hline Fiscal Year & National Poverty Line $(\%)$ & Rural & Urban \\
\hline $1991-1992$ & 58.8 & 61.2 & 44.9 \\
\hline $1995-1996$ & 53.1 & 56.7 & 35.2 \\
\hline $2000-2001$ & 49.8 & 52.3 & 35.0 \\
\hline $2004-2005$ & 40.0 & 43.8 & 28.4 \\
\hline $2010-2011$ & 31.5 & 35.2 & 21.3 \\
\hline $2010-2016$ & 24.3 & 26.4 & 18.9
\end{tabular}

Source: i) BBS, Household Income \& Expenditure Survey (HIES-2005), ii) BBS, Household Income \& Expenditure Survey (HIES-2010), iii) BBS, Household Income \& Expenditure Survey (HIES-2016).

As stated in the Figure 1, the highest poverty fell to $40 \%$ in 2005, down from almost $50 \%$ in 2000 . $10 \%$ of Bangladesh's population was lifted out of poverty during 1999s; the same feat was accomplished again in the first five years of the millennium. It is also observed that over the last twenty years, almost every year, and the rural poverty headcount declines with different slopes.

However, the above statistics provide only counted statistical data, but actually, the real structure of poverty and overcrowding has pushed the countless poor in Bangladesh to seek their livelihoods in more and more unsafe areas of the country and more vulnerable ways. 


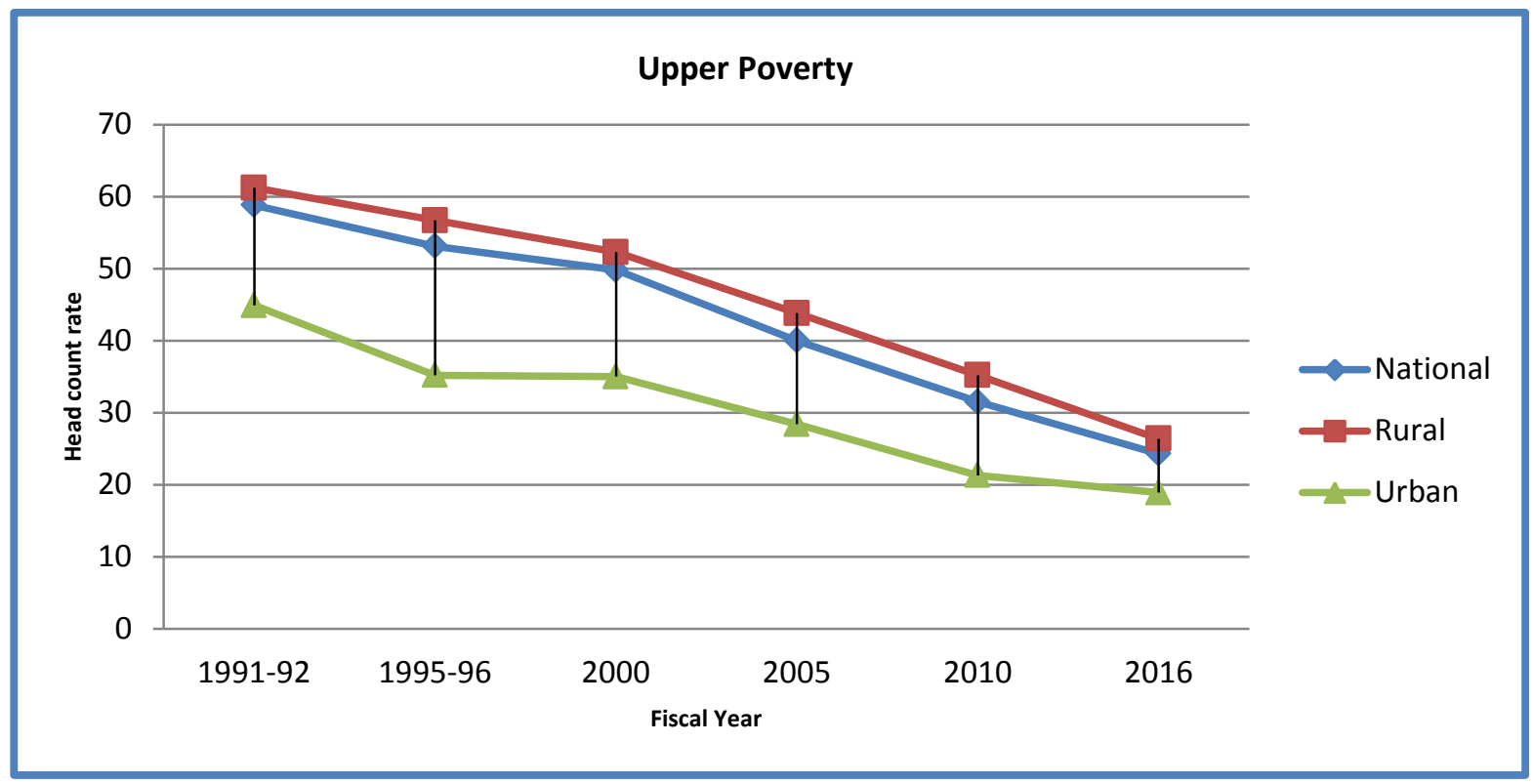

Figure 1. Upper poverty line between 1991 and 2016

Sources: Bureau of Bangladesh Statistics (BBS)

To meet up such challenges, the prime needs of rural improvement in Bangladesh have been diagnosed as production and income-generating activities in both farm and non-farm sectors. Thus, Interest-free microfinance can contribute lots to get rid of poverty through income-generating activities.

\section{Contribution of RDS in Bangladesh}

Rural Development Scheme of IBBL has become a brand among the Muslim world as an interest-free microfinance application which market share is almost $50 \%$ of total microfinance outreach. Every sector of the rural economy has gained a positive impact through the RDS of IBBL. Covering all socio-monetary factors, RDS becomes the best performance-oriented microfinance activities in Bangladesh (UNDP, 2012); (Ahmed, 2004). RDS plays a vital role in the development of the standard of living through the relationship of household earnings and expenditure (Rahman et al., 2008).

\subsection{Towards Financial Inclusion}

\subsubsection{No. Village, Centers and Branches}

As shown in figure 2 below, how the operation has been allotted for selected years. RDS was offered with only 118 branches at the end of 2006, which accelerated to 272 branches at the end of the year 2018. These branches are scattered in sixty-four districts and six divisions. An increase in number of centers has outnumbered all different segments, which was only 15321 at the end of 2006 and ended up at 30112 in 2018 . However, direct employee per center has reduced drastically, which is a place of difficulty for member-management in a group based micro-investment program. A boom of no of villages which was only 8057 at the end of 2006 and ended up at 21992 in 2018. 


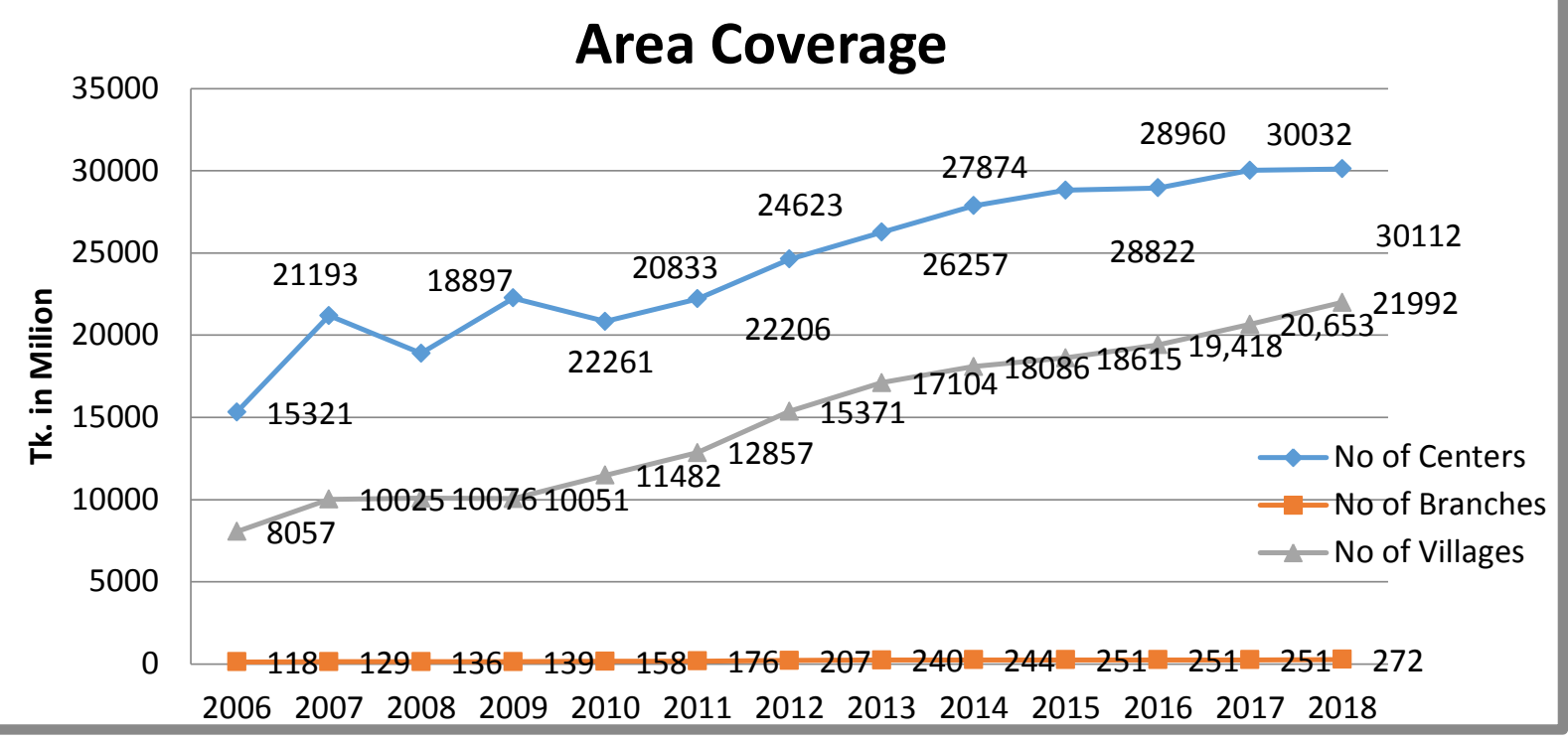

Figure 2. Number of village, centers \& branches of RDS over the years

Source: IBBL Annual Report (2006-2018)

Note: Data compiled by the researcher

RDS is predicted to be introduced in the rural areas of the country step by step. It has already been covered 21992 villages (32.32\% of the total villages in Bangladesh).

3.1.2 Number of Members \& Clients

As shown in Figure 3, in the RDS scheme, the member who received funding facilities is referred to as clients. Increase in range of participants, which was only 409,573 at the end of 2006 and ended up at 1,108,283 in 2018. Increase in the number of clients, which were only 315424 in the given the year of 2006 and ended up at 625532 . It implies that RDS has members as well client base who generally have no intention to switch other NGOs.

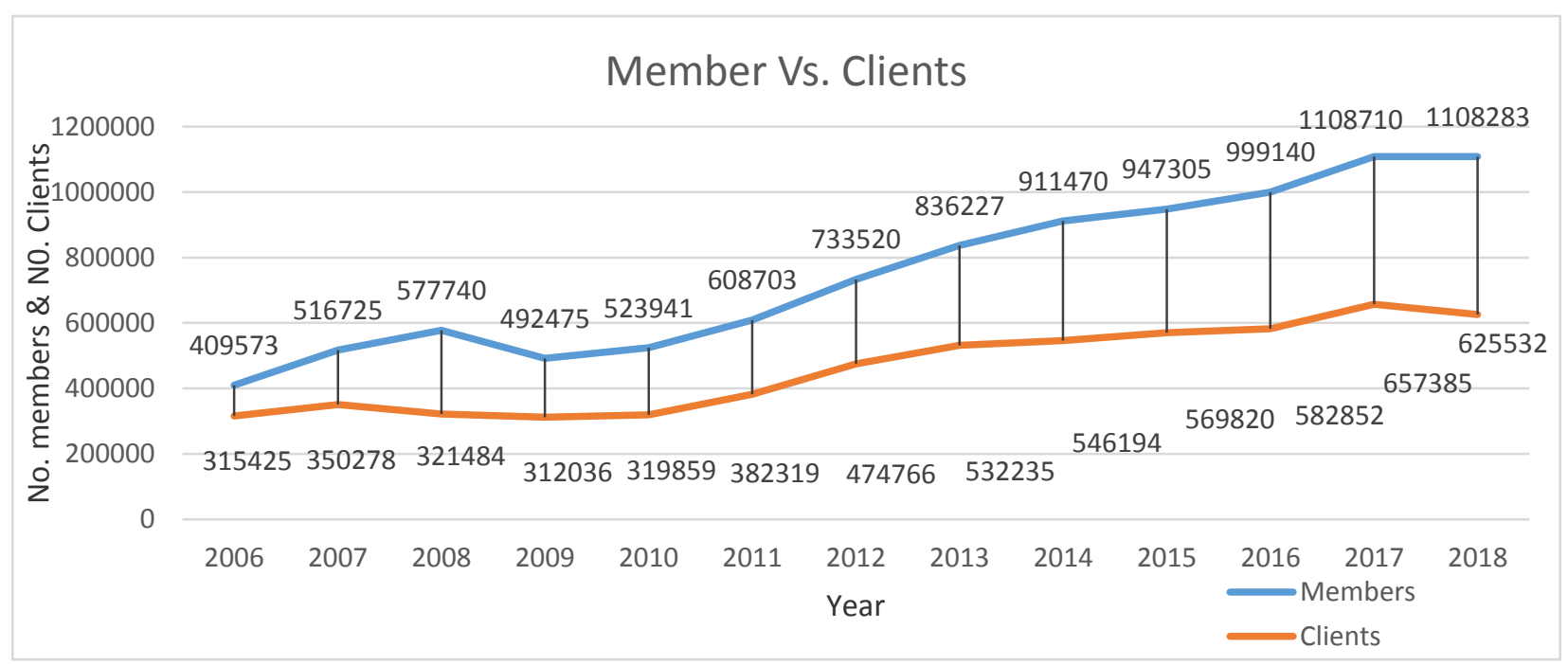

Figure 3. Showing number of members and clients over the study periods

Source: IBBL Annual Report (2006-2018) 
The overall performance of RDS largely relies upon how many members, in addition to customers, have been brought under the net of the program. Of course, the program has particular criteria for selecting rural people for making members of the group as well as of center and granting them micro-investment.

\subsubsection{Share of IBBL in Country's Microfinance}

Islami Bank Bangladesh Limited (IBBL), the largest commercial bank of Bangladesh, introduces a microfinance program in 1995 which now shares nearly $50 \%$ of the whole Islamic microfinance of the world. According to the microfinance of records in 2010, the RDS program has experienced the maximal growth in evaluation with different microfinance institutions. The RDS saw a growth of 6.39\%, the second-highest after Palli Daridro Bimochon foundation (PDBF), a conventional microfinance institution in Bangladesh.

Table 2. Share of IBBL in country's microfinance

\begin{tabular}{ll}
\hline Share of IBBL's Microfinance to PCBs & $52.05 \%$ \\
\hline Share of IBBL to SCBs \& PCBs & $25.85 \%$ \\
\hline Share of IBBL to PCBs retail microfinance & $98.90 \%$ \\
\hline IBBL share in country microfinance through banking \& public institutes & $8.05 \%$ \\
\hline
\end{tabular}

Source: Investment Development Forum 2014/2015“

\section{Methodology of the Study}

\subsection{Population and Sampling}

Among various areas of the country, some areas of the Rajshahi division were purposively selected by the researcher for study purposes. For study purposes, Natore \& Joypurhat district under Rajshahi Division was selected by the researcher. It was observed during the pilot survey, most of the poor or hardcore poor live in these areas and sample Islamic microfinance institution (IBBL) has been working in these areas for providing financial services. This research used purposive sampling irrespective of probability sampling because of time and resource constraints. Respondents were selected using the database of more than 7500 clients of RDS and with the help of the field officers of the RDS program. Finally, the total number of respondents interviewed for field survey was 328 from target borrowers of the respective rural financial institution (IBBL).

Data was summarized, coded, and tabulated through charts, graphs. Descriptive statistics include frequency distribution; mean, standard deviation, as well as financial ratios, was used for data analysis. Many researchers prefer to use a Likert-type scale because it's effortless to analyze statistically (Jackson, 2009, p. 89). Data were coded and analyzed using SPSS. The summary of the data was done using charts and tables. To determine whether income before obtaining micro-investment was significantly different from that of after getting the investment, event analysis technique was computed where the cumulative change in income after receiving microfinance investment was tested using hypothesis testing at a $95 \%$ confidence level.

Statistical indicators that were used are the F-test, t-test, $\mathrm{z}$ test, and level of significance. The significance of each independent variable was tested. F-test was used to test the validity of the overall model considering a 5 percent confidence level. The p-value for the F-statistic was applied in determining the robustness of the model. Independent variables (determinants of microfinance, investment) with a P-value of less than $5 \%$ were declared to have a significant effect on poverty alleviation.

\subsection{Data Collection}

Data had been collected, ensuring the following process, this process also followed by other researchers (Nader, 2008), (Hassan, Hassan, Saleem, \& Saleem, 2017).

- Program documents, customer information archives, rules to be a member of RDS, and mechanisms are verified properly.

- Both close-ended and open-ended questions were used to make a face to face interview. Before running, the survey questionnaires were tested for its understanding of the participants, who are from a very poor background. 


\subsection{Analytical Model}

A multivariate regression model was applied to determine the relative importance of each of the six variables (business expansion, housing and shelter, saving, child education, health care, and better clothing) with respect to poverty alleviation.

The regression model was as follows:

$$
Y=\beta_{0}+\beta_{1} X_{1}+\beta_{2} X_{2}+\beta_{3} X_{3}+\beta_{4} X_{4}+\beta_{5} X_{5}+\beta_{6} X_{6}+\epsilon
$$

Where;

$\mathrm{Y}=$ Poverty alleviation

$\beta_{0}=$ Constant term

$\beta_{1-6}=$ Are coefficients used to measure the sensitivity of the dependent variable (Y) to a unit change in the predictor variables.

$X_{1}=$ Microfinance Investment

$X_{2}=$ Business Expansion

$X_{3}=$ Housing and Shelter (Accommodation status)

$X_{4}=$ Saving

$X_{5}=$ Child Education

$X_{6}=$ Healthcare/Medical treatment/Medical facilities

$\epsilon=$ is the error term to capture unexplained variations in the model and which is assumed to be normally distributed with mean zero and constant variance.

The selections of the variables are done by investigating different existing pieces of literature; variables details are shown in Table 1 in the following.

Table 3. Description of the variables

\begin{tabular}{lll}
\hline Variable & Indicator & Previous findings of the relation with Poverty alleviation \\
\hline Dependent variable & & \\
\hline Poverty alleviation & Level of household income (Y) & \\
\hline Independent variables & Uptake of microfinance as RDS & $\begin{array}{l}\text { Microfinance programs have aptitudes in poverty } \\
\text { alleviation, particularly increasing income, reduction of } \\
\text { vulnerability that will stimulate people's economic } \\
\text { capacity as well as sustainable development (Akinlabi, } \\
\text { Kehinde, \& Jegede, 2011). }\end{array}$ \\
\hline Investment & from IBBL (X1) &
\end{tabular}

\begin{tabular}{l}
\hline Business $\quad$ Changes in the stock levels (X2) \\
Expansion
\end{tabular}

Household, having basic coverage, can have scope to use borrowed funds for expansion of Business as the level of income and living conditions improved. (Waiganjo, 2008)

\begin{tabular}{|c|c|c|}
\hline $\begin{array}{l}\text { Housing and } \\
\text { Shelter } \\
\text { (Accommodation } \\
\text { status) }\end{array}$ & $\begin{array}{l}\text { Expenditure on rent, Relocation } \\
\text { to } \quad \text { better-perceived } \\
\text { neighborhoods (X3) }\end{array}$ & $\begin{array}{l}\text { Urban poverty is a prime reason for insufficient shelter. } \\
\text { The financial constraints of individuals and households } \\
\text { lead to rent low-quality accommodation, build, } \\
\text { informally, and illegally as No other alternative remains } \\
\text { available for the living people of the Southern cities and } \\
\text { Towns. Even individual home construction is slow due to } \\
\text { a shortage of finance, and a lack of spread cost arrange } \\
\text { through attaining a loan (Denis, 2003). }\end{array}$ \\
\hline
\end{tabular}

Saving Increase in saving (X4) Savings habits can be the most effective way to end


poverty (Mauri, Dell'Amore, Masini, \& Mottura, 1983).

\begin{tabular}{lll}
\hline Child Education & Enrollment in best-rated schools & $\begin{array}{l}\text { Microfinance loan is likely to be a productive investment } \\
\text { in alleviating poverty and improving children's education } \\
\text { (X5) }\end{array}$ \\
& & and nutrition status. (Khandker, 2005).
\end{tabular}

Healthcare/Medical Improved sanitation Access to treatment/Medical private health facilities (X6) facilities
Peters et al. (2008) proclaims that the relationship between access to health care facilities and poverty is positively related as poverty results illness and unhealthy condition leads to poverty.

Description: Table shows the indicators and previous studies regarding the selected variables.

\section{Findings and Analysis of the Results}

\subsection{Descriptive Statistics}

The questionnaire was developed to target population size of 350 respondents from which 328 questionnaires were filled, representing a response rate of $93 \%$. This response rate was satisfactory to make the conclusions of the study. The high rate was attributed to the approach of administering the questionnaires through interviews, and aggressively follow up on self-administered questionnaires. $100 \%$ of the respondents were beneficiaries of the microfinance program of IBBL and hence provided relevant data required by the study.

\subsubsection{Respondents Monthly Income Level Range}

The majority of the respondents had a monthly income of Tk. below 5,000 at $61 \% .23 \%$ of the respondents had income levels, Tk. 5001 to Tk. 10000 per month, 13\% had a monthly income of Tk. 10001 to Tk. $15000,2 \%$ of the respondents had an income of Tk 15001 to Tk. 20000 while $2 \%$ had monthly income above Tk. 20,000.

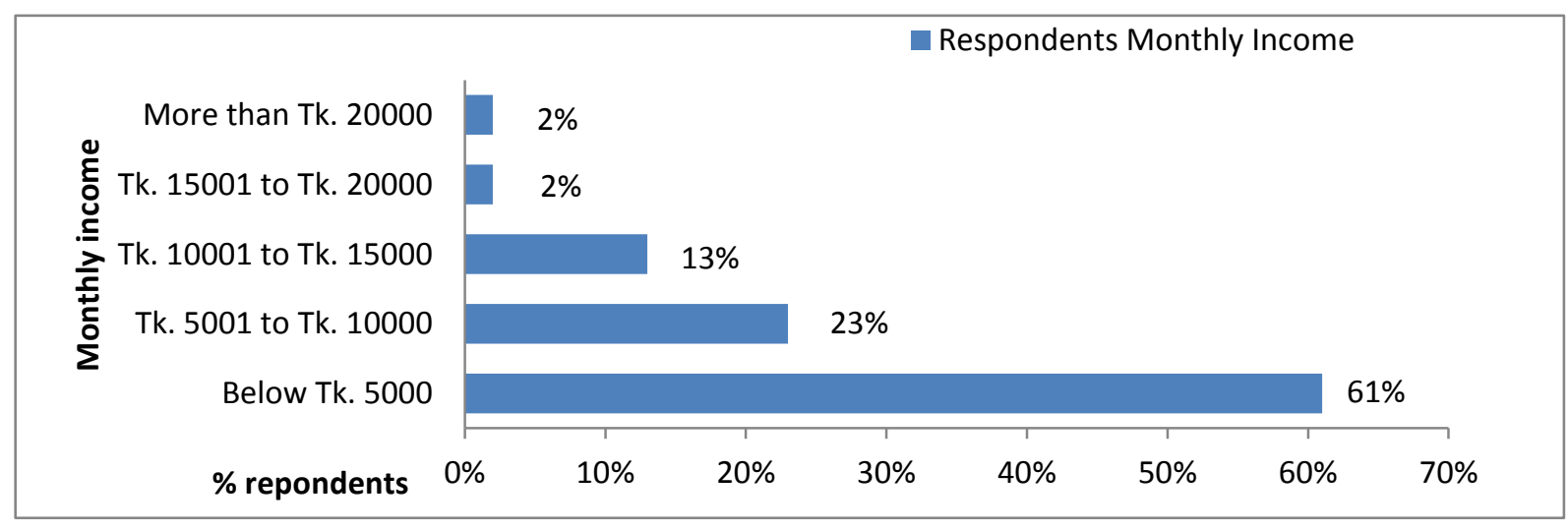

Figure 4. Monthly income level of respondents

Source: Research Findings

Note: Data compiled by the researcher

\subsubsection{Uses of Microfinance by the Borrowers/Clients}

This part sought to determine how the respondents implemented the funding financing obtained. $42 \%$ of respondents used the funding for agricultural activity's purpose (cultivation, farming, etc.). $32 \%$ used, the amount either expand business or starting the business, $10 \%$ used to purchase car rickshaw, van, etc., $8 \%$ improves for housing and shelter, $2 \%$ used for micro-enterprising, $1 \%$ used for making handicrafts, $6 \%$ used for different purposes. It is encouraging to find that the majority of the respondents taken investment for agricultural purposes and to expand business enterprise and housing. The details are shown in Figure 5 below. 


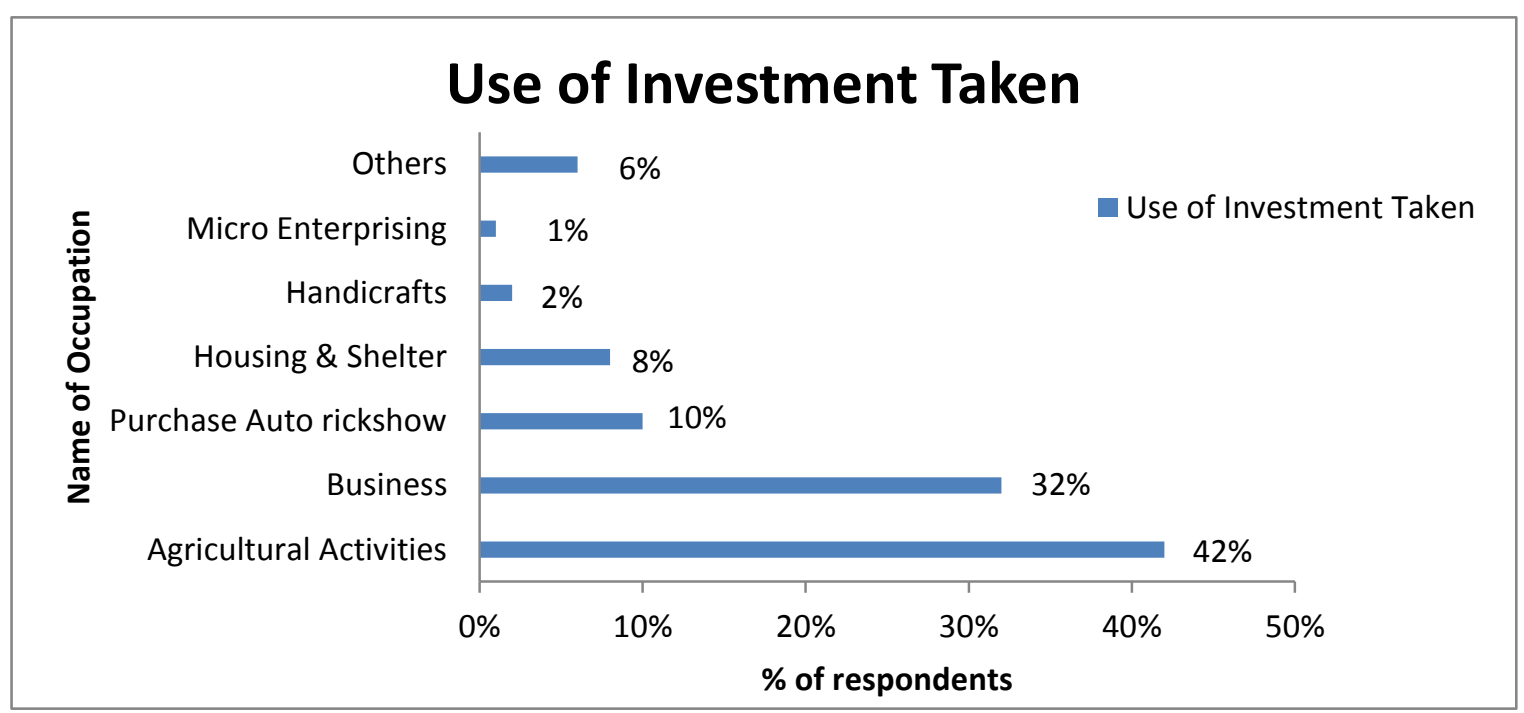

Figure 5. Uses of microfinance

Source: Field Survey

Note: Data compiled by the researcher

\subsubsection{Challenges in Repaying Microfinance Loan Obtained}

As shown in figure 6 below, $74 \%$ of the respondents had challenges in repaying the microfinance loans, while $26 \%$ had not. This implies that if having challenges could mean that their incomes had increased, then only $26 \%$ of the respondents had an effect on household incomes. Of those who had challenges in repaying the loans obtained explained that it was as a result of the lack of source of income to pay for (54\%), investment was mainly used for non-income generating activity $(27 \%)$, diversion of funds from its intended purpose (18\%), the poor market for produce (32\%), due to the natural/accidental disaster (31\%) and others (3\%).

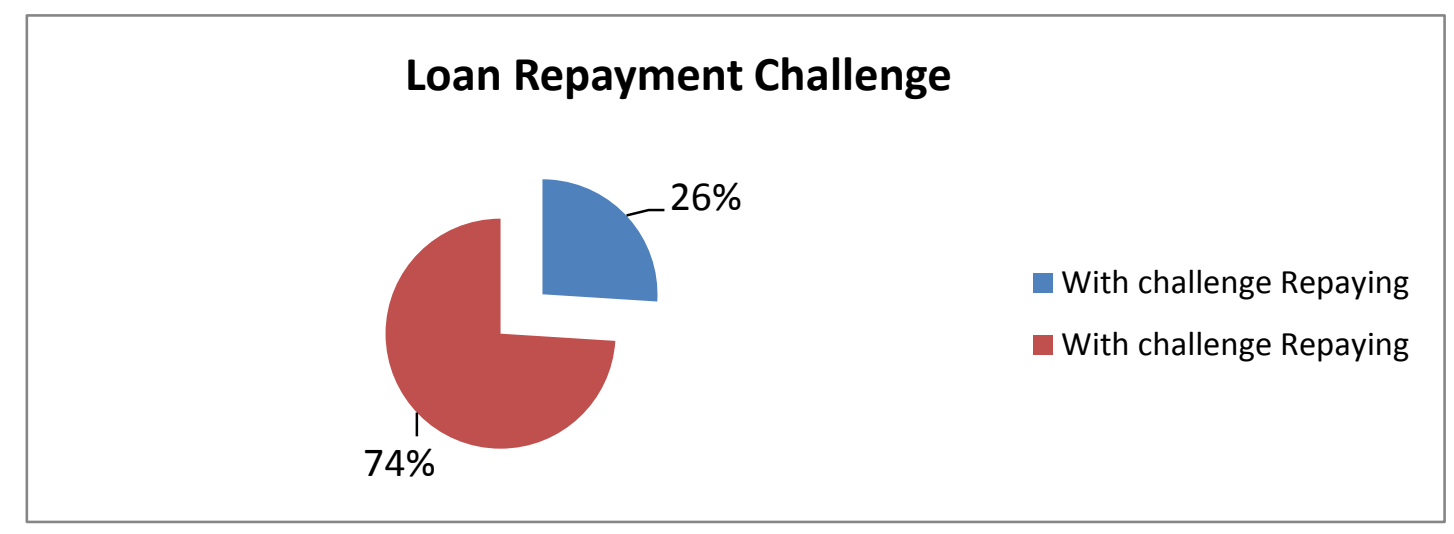

Figure 6. Loan repayment challenges respondents

Source: Research Findings

Note: Data compiled by the researcher

\subsubsection{RDS \& Others Microfinance Ratio}

This part sought to determine whether the client of RDS has taken any facilities from other microfinance institutions or not. As shown in the figure below, $16 \%$ of respondents have taken both facilities at a time. $84 \%$ of respondents have taken financial facilities from only RDS of IBBL. 


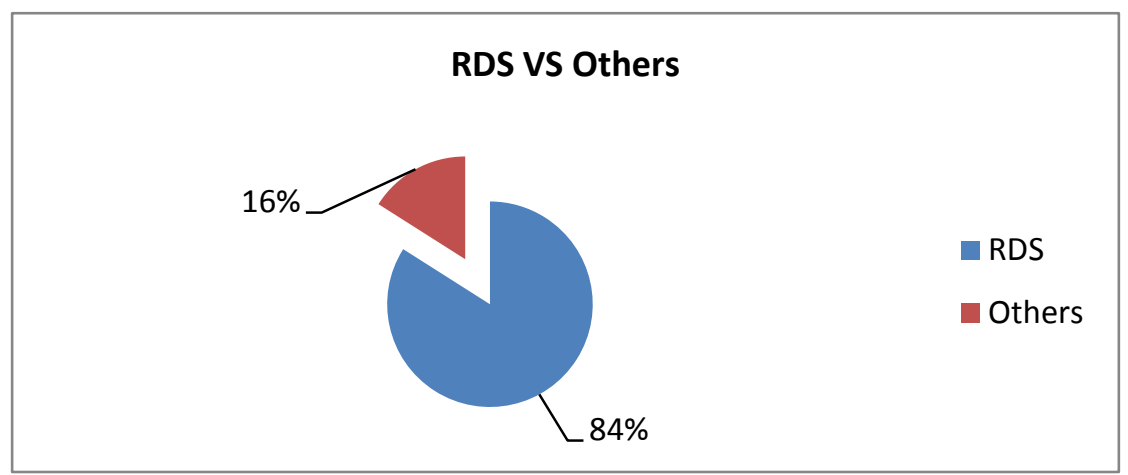

Figure 7. Microfinance support from RDS VS other institutions

Source: Research Findings. Note: Data compiled by the researcher

\subsubsection{Benefits of Microfinance Loan Obtained}

This part examines the respondents' assessment of micro-investment. 99\% of the respondents agreed that microfinance investment access had benefited them, with $1 \%$ indicated that they never benefited from the investment access. As shown in Table 6.1 below, $53 \%$ of the respondents indicated that micro-investment finance had helped them improve their businesses, $65 \%$ indicated that the same enabled the development of better housing, $70 \%$ were able to access better education of their children; as a result, $63 \%$ were able to improve sanitation facilities to a greater extent while $9 \%$ were benefited in other ways.

Table 4. Benefits of microfinance

\begin{tabular}{lll}
\hline Benefits of Microfinance & Frequency & Percentage \\
\hline Investment has helped improve my business & 173 & $53 \%$ \\
\hline Investment has facilitated access to children education & 213 & $65 \%$ \\
\hline Investment has enabled the development of better housing & 229 & $70 \%$ \\
\hline Investment has helped improve the sanitation system & 208 & $63 \%$ \\
\hline Other & 29 & $9 \%$ \\
\hline
\end{tabular}

Source: Survey Data \& Data compiled by the researcher

\subsubsection{Use of Micro-Investment in Business}

$38 \%$ of the respondents were engaged in the business from which all respondents were using microfinance investment/. As shown in Table 5 below, as a result of the use of micro-investment, $49 \%$ were able to increase their stock levels, increase products and services offered (45\%), expand their business (19\%), increase in the number of employees (18\%) and other forms of growth (4\%). This implies that micro-investment has a positive effect on business growth.

Table 5. Micro-investment effect in business activities

\begin{tabular}{lll}
\hline Effect of microfinance investment & Frequency & Percentage \\
\hline Increase in stock levels & 162 & $49 \%$ \\
\hline Increase in products and services offered & 146 & $45 \%$ \\
\hline Expansion of business to more than one shop & 61 & $19 \%$ \\
\hline Increased number of employees & 58 & $18 \%$ \\
\hline Other & 12 & $4 \%$ \\
\hline
\end{tabular}

Source: Survey Data \& Data compiled by the researcher 


\subsubsection{Perceptions Regarding RDS of IBBL}

As shown in the table below 6.3, 98\% of respondents received a suggestion on behalf of bank to overcome the difficulties to do make income-generating activities. $63 \%$ of respondents participated in a various kind of training program arranged by the bank, only $17 \%$ think that pre-requisites of getting investment are cumbersome, $92 \%$ think that joint liability or group liability system is helpful to pay loan installment while $94 \%$ respondents are happy with RDS of IBBL in Bangladesh.

Table 6. Rate of response of respondents

\begin{tabular}{lll}
\hline Question asked by field Officer & Frequency & Percentage \\
\hline $\begin{array}{l}\text { Whether the bank officials suggest, you overcome the difficulties in } \\
\text { income-generating activities. }\end{array}$ & 320 & $98 \%$ \\
$\begin{array}{l}\text { Did you participate in any training program organized by the funding institution } \\
\text { before starting income-generating activities? }\end{array}$ & 207 & $63 \%$ \\
$\begin{array}{l}\text { Do you think that the pre-requisites of getting a selection of loans by the lending } \\
\text { institution are cumbersome? }\end{array}$ & 56 & $17 \%$ \\
$\begin{array}{l}\text { Do you think that a "joint liability or group liability" system is helpful for you to } \\
\text { pay loan installment. }\end{array}$ & 303 & $92 \%$ \\
$\begin{array}{l}\text { Could you use the loan at your own decision? } \\
\text { Are you happy about being a member of the Islamic micro-investment/ program? }\end{array}$ & 309 & $20 \%$ \\
\hline
\end{tabular}

Source: Survey Data \& Data compiled by the researcher

\subsubsection{Changes in Income Before and After Microfinancing}

Table 7 shows majority of the respondents had a monthly income of Tk. below 5,000 at $61 \% .23 \%$ of the respondents had income levels, Tk. 5001 to Tk. 10000 per month, 14\% had a monthly income of Tk. 10001 to Tk. 15000, 1\% of the respondents had an income of Tk. 15001 to Tk. 20000 while 1\% had monthly income above Tk. 20,000.

Table 7. Income before entering to microfinance

\begin{tabular}{lll}
\hline \multirow{2}{*}{ Income Range } & Before microfinancing & \\
\cline { 2 - 3 } & Frequency & Percentage \\
\hline A. Below Tk. 5,000 & 201 & $61 \%$ \\
\hline B. Tk. 5,001- 10,000 & 74 & $23 \%$ \\
\hline C. Tk. 10,001- 15,000 & 42 & $14 \%$ \\
\hline D. Tk. 15,001- 20,000 & 5 & $1 \%$ \\
\hline E. More than Tk. 20,000 & 6 & $1 \%$ \\
\hline
\end{tabular}

Source: Survey Data \& Data compiled by the researcher

The table below eight shows, after microfinance investment access to the RDS scheme of IBBL, the number of respondents with monthly income below Tk. 5,000 remained the same as $28 \%, 58 \%$ increased from below tk. 5000 to $5001-10000,12 \%$ increased to $10001-15000$ while $2 \%$ increased to 15001 to 20000 . It has been found that overall, $72 \%$ of respondent's incomes increased in any category more than 5001 to 10000. 
Table 8. Income after microfinancing

\begin{tabular}{lll}
\hline \multirow{2}{*}{ Income Range } & After Microfinancing & \\
\cline { 2 - 3 } & Frequency & Percentage \\
\hline A. Below Tk. 5,000 & 92 & $28 \%$ \\
\hline B. Tk. 5,001- 10,000 & 190 & $58 \%$ \\
\hline C. Tk. 10,001- 15,000 & 40 & $12 \%$ \\
\hline D. Tk. 15,001- 20,000 & 7 & $2 \%$ \\
\hline E. More than Tk. 20,000 & 0 & - \\
\hline
\end{tabular}

Source: Survey Data \& Data compiled by the researcher

\subsubsection{Factor Influencing on Borrower's Socio-Economic Development}

For evaluating some of the other socio-economic development factors of the target respondent's opinions were also sought from the borrowers/clients about their socio-economic development factors depending on some indicators. As shown in table 9, different development indicators. A Five-Point Likert Scale has been used to evaluate the clients' socio-economic development; each statement had five options, which were; Highly Satisfactory (HS), Satisfactory (S), Neutral (N), Dissatisfactory (D) and Highly Dissatisfactory (HD). Weight has been given for each option, such as $\mathrm{HS}=5, \mathrm{~S}=4, \mathrm{~N}=3, \mathrm{D}=2, \mathrm{HD}=1$.

Table 9. Borrower's socio-economic development

\begin{tabular}{lllllll}
\hline & \multicolumn{3}{l}{ Degree of Satisfaction } & \multicolumn{3}{c}{ Weighted Rank } \\
\cline { 1 - 5 } Name of the Socio-Economic indicators & HS $(5)$ & $\mathrm{S}(4)$ & $\mathrm{N}(3)$ & $\mathrm{D}(2)$ & $\mathrm{HD}(1)$ & 4.1 \\
\hline Sanitation facilities & 90 & 163 & 8 & 61 & 6 & 4.4 \\
\hline Pure drinking water & 57 & 230 & 19 & 12 & 10 & 4.3 \\
\hline Participation in family decision making & 53 & 233 & 13 & 29 & 42 & 3.7 \\
\hline Improve Social Status & 64 & 166 & 58 & 38 & 2 & 3.3 \\
\hline Participating in social programs & 35 & 170 & 82 & 29 & 12 & 3.5 \\
\hline Excising voting right & 55 & 159 & 84 & 29 & 1 & \\
\hline
\end{tabular}

Source: Survey Data \& Data compiled by the researcher

During the time of the interview with the target clients/borrowers, the researcher also sought their opinions about various activities in their life. Their opinions are measured through the Five Point Scale as Rank wise. Table 9 reveals that pure drinking water facilities have been given the highest score (4.4) by the respondents; Participation in family decision-making activities (4.3), sanitation facilities (4.1), excising voting rights and improve social status are given $4^{\text {th }}$ and $5^{\text {th }}$ score. The participating in social programs got the lowest score by 3.3 .

It can be concluded from the above findings that the Micro-investment program of RDS of IBBL has a significant impact on the socio-economic development of the poor rural households in the study area.

\subsection{Assessment of Impact of RDS in Alleviating of Poverty}

This research is conducted through a multiple regression analysis to determine the effect of microfinance on poverty alleviation at the household level in two districts of the Rajshahi Division in Bangladesh. Multiple regressions are a statistical technique that allows us to predict a score of one variable based on their ratings on several other variables. The main purpose of numerous regressions is to learn more about the relationship between several independent or predictor variables and a dependent or criterion variable. 


\subsubsection{Effect of Microfinance on Household Income}

To determine whether income before the adoption of micro-investment was significant and after the approval of micro-investment from IBBL, hypothesis testing between the mean income before and after accessing microfinance investment was conducted at $95 \%$.

Here, $\mathrm{H}_{0}: \mathrm{X}_{\mathrm{B}}=\mathrm{X}_{\mathrm{A}}$

$$
H_{\mathrm{a}}: \mathrm{X}_{\mathrm{B}} \neq \mathrm{X}_{\mathrm{A}}
$$

Table 10. Improvement as result micro-investment

\begin{tabular}{lll}
\hline Period & Mean Income & Standard Deviation \\
\hline Before & 1.60 & 0.900 \\
\hline After & 2.58 & 1.141
\end{tabular}

Source: Research Findings \& data compiled by the researcher

The $\mathrm{Z}$ test obtained was 4.52 , which was more significant than the critical value $\mathrm{Z} \pm 1.96$ (two-tailed test). Hence, the null hypothesis rejected. There was no difference in the mean income before and after microfinance investment access.

Since the $\mathrm{Z}$ computed was falling in the rejection area, the null hypothesis was rejected, and an alternative hypothesis accepted. This meant that microfinance investment access had a statistically significant effect on household income at a 95\% confidence interval. This result matches the previous researcher's findings such as: (Imai \& Azam, 2012), (Al-Shami, Majid, Mohamad, \& Rashid, 2017), (Ghalib, Malki, \& Imai, 2015) who found that there is a positive and significant impact of microfinance on household income, food consumption, personal asset.

\subsubsection{Impact of RDS on Poverty Alleviation}

A multivariate regression model was applied to determine the effect of Microfinance investment of the Rural Development Scheme of IBBL on poverty alleviation at the household level in two districts of the Rajshahi Division in Bangladesh. As shown in Table 11 below, there is a strong positive relationship between poverty alleviation and microfinance investment. This is demonstrated by the Spearman coefficient of correlation of 0.974 or 0.97 . The coefficient of determination of 0.95 implies that the independent variables account for $95 \%$ of changes in the independent variables. Therefore micro-investment of RDS of IBBL accounts for $95 \%$ changes in household income.

Table 11. Regression model summary

\begin{tabular}{llll}
\hline $\mathrm{R}$ & R Square & Adjusted R Square & Std. Error of the Estimate \\
\hline .974 & .950 & .949 & .257 \\
\hline
\end{tabular}

Source: Research Findings \& data compiled by the researcher

The ANOVA results are presented in Table 12 below. As shown in the table, the p-value obtained 0.000, which is less than 0.05 . This implies that the model developed can be relied on for prediction. At the $95 \%$ confidence level, therefore, the relationship between microfinance of IBBL and poverty is very significant. Hence the calculated value (1007.361) is higher than the critical value or table \pm 1.96 ; the null hypothesis is rejected. It implies that the Rural development scheme of IBBL has a significant impact on poverty alleviation.

Table 12. Analysis of the variance (ANOVA)

\begin{tabular}{lllllll}
\hline Model & & Sum of Squares & df & Mean Square & F & Sig. \\
\hline \multirow{2}{*}{ Regression } & 398.168 & 6 & 66.361 & 1007.361 & $.000 \mathrm{~b}$ \\
\cline { 2 - 7 } & Residual & 21.146 & 321 & .066 & & \\
\cline { 2 - 7 } & Total & 419.314 & 327 & & &
\end{tabular}

Source: Research Findings 
The coefficients of the model developed by the study are presented in table 13 below. Notably, all the coefficients obtained are positive, implying that the amount of microfinance investment obtained, an amount of spending of business expansion, those spent on housing, savings, education \& health care increases household income \& hence poverty alleviation.

Table 13. Regression model coefficients

\begin{tabular}{|c|c|c|c|c|c|c|}
\hline \multirow[b]{2}{*}{ Model } & & \multicolumn{2}{|c|}{ Unstandardized Coefficients } & \multirow{2}{*}{$\begin{array}{l}\text { Standardized Coefficients } \\
\text { Beta }\end{array}$} & \multirow[b]{2}{*}{$\mathrm{t}$} & \multirow[b]{2}{*}{ Sig. } \\
\hline & & B & Std. Error & & & \\
\hline \multirow[t]{7}{*}{1} & (Constant) & .151 & .065 & & 2.333 & .020 \\
\hline & Micro-Investment (RDS) & .236 & .082 & .051 & 2.894 & .004 \\
\hline & Business Expansion & .234 & .080 & .086 & 2.936 & .004 \\
\hline & Accommodation Status & .404 & .054 & .391 & 7.526 & .000 \\
\hline & Savings Increase & .148 & .045 & .151 & 3.316 & .001 \\
\hline & Education Opportunity & .127 & .039 & .155 & 3.268 & .001 \\
\hline & Medical Facilities & .170 & .022 & .209 & 7.682 & .000 \\
\hline
\end{tabular}

Source: Research Findings

The model developed by the study is $\mathrm{Y}=.151+.236 \mathrm{X}_{1}+.234 \mathrm{X}_{2}+.404 \mathrm{X}_{3}+.148 \mathrm{X}_{4}+.127 \mathrm{X}_{5}+.170 \mathrm{X}_{6}$; where $\mathrm{Y}$ is poverty alleviation, $X_{1}$ is a micro-investment, $X_{2}$ is business expansion, $X_{3}$ is accommodation status, $X_{4}$ is savings, $X_{5}$ is an educational opportunity, and $\mathrm{X}_{6}$ is healthcare or medical facilities.

All the coefficients are significant since their $\mathrm{P}$ values are less than 5\%. It implies that independent variables such as micro-investment, business expansion, accommodation status, savings education opportunity, and medical facilities have been found to have a significant impact on poverty alleviation of the clients of the Rural Development Scheme (RDS) under study. These findings are also supported by many past researchers such as: Iqbal, Iqbal, and Mushtaq (2015) showed that there is a positive impact of microfinance on the fulfillment of basic needs, self-employment, and living standard leading towards poverty alleviation, and Enisan \& Oni (2012) mentioned that access to credit helped recipients to reap the benefits of economic opportunities by offering a fundamental basis for the preparation and expansion of business activities. Some others also found the same results for instance: (Idowu \& Oyeleye, 2012), (Boateng, Boateng, \& Bampoe, 2015), (Nawaz, 2010), (Garikipati, 2017), (Rokhman, 2013) and so on.

\section{Conclusion, Recommendations, and Avenues for Further Study}

This study has an attempt to locate the position of the rural development microfinance scheme of IBBL. From the survey, it is found out that microfinance, investment performs an essential part in the alleviation of poverty in Bangladesh with family income after access to microfinance is found to increase significantly. The income levels have gone up of all members after becoming a member of RDS. This has led to higher food security for the poor. The higher-level of income has again been translated into better expenditure for food items and different goods \& services. As time passes, RDS individuals have a tendency to consume proper meals, and this leads to a better consumption of nutrients. Based on the findings, the study concludes that the micro-funding (RDS) of Islamic Bank Bangladesh plays a crucial position in the comfort of poverty at the household degree in Bangladesh. The study additionally concludes that micro-investment assists in poverty reduction by way of imparting, making finance at hand to low-income earners, less educated, and those within the informal sector, which helps in the growth of the business, acquisition of higher housing and shelter, entry to education, health $\&$ advanced welfare. It is also visible as a crucial enter for small-scale enterprises in the rural vicinity of Bangladesh. IBBL has a notable commencement manner wherein the status of s customers has changed to upward. Under the microfinance program, customers are being cared to be advanced gradually. Apart from, they are supplied with capacity building training, counseling, and other logistics. One of the most significant changes that have taken place in RDS program families is the advent of employment opportunities, especially for women, leads to achieving the MDGs. The introduction of housing investment and investment in such things as a restroom, education, tube wells, and others might attract general people to come in the umbrella of the RDS. Therefore, microfinance is an effective technique of poverty remedy since it targets those who earn less. 
Considering the summaries of the main findings of the study, the following proposed recommendations, as well as policy implications, can be drawn to accelerate the growth of Islamic microfinance in Bangladesh:

$>$ IBBL, along with other government and non-government institutions, should come forward with specialized training and motivation programs with the purpose of the development of communication skills and awareness of rural people regarding Islamic financial products \& services.

$>$ The findings of the study also confirmed that this program could be suitable only for a specific group of people poses strong Islamic believes. Hence banks should invest this program to all of its branches to bring more people under the umbrella of Islamic microfinance.

$>$ The central bank may formulate separate guidelines for the smooth running of Islamic microfinance operated by the scheduled bank.

$>$ The rules and regulations should be relaxed for the microfinance of the bank like NGOs under the license of MRA.

$>$ The repayment system should start at least after one month of taking a loan, and should be based on the nature of cash flow being generated from the farm and non-farm activities like seasonal cash flow and regular cash flow.

$>$ Studies found that only members of the RDS of IBBL know about Islamic microfinance. So, awareness programs should spread out beyond the member of RDS.

$>$ The study recommends that RDS activities be extended towards hardcore poor, especially for widows and divorcees. Monitoring and supervision should be strengthened, while more ethical and moral motivational programs have to be undertaken for both field supervisors and clients to reduce Shariah violation.

Further research can be done regarding the role of commercial banks to relieve poverty, having many have the physical infrastructure, including an extensive network of branches, from which to expand and reach out to a large range of micro-finance customers, particularly Islami Banks in Bangladesh. Commercial banks have well-established internal controls and administrative and accounting systems to keep track of a large number of transactions. They have their sources of funds (deposits and equity capital); they do not must depend upon scarce and unstable donor resources (as do NGOs). This study advocated further studies about the role of other commercial banks in alleviating poverty within the rural area.

\section{References}

Abul, B. B., Chamhuri, S., Abdul, G. I., \& Basri, T. (2011). Islamic microcredit is the way of alternative approach for eradicating poverty in Bangladesh: a review of Islami Bank Microcredit Scheme. Australian Journal of Basic and Applied Sciences, 5(5), 221-230.

Ahmed, H. (2004). Frontiers of Islamic banks: A synthesis of the social role and microfinance. Munawar Iqbal Islamic Banking in Practice 10. In S. M. Elfakhani, Y. M. Sidani, \& O. A. Fahel (Eds.), An Assessment of the Performance of Islamic Mutual Funds 39 Obiyathulla Ismath Bacha Value Preservation through Risk Management A Shariah Compliant Proposal for Equity Risk (p. 118).

Akinlabi, B. H., Kehinde, J., \& Jegede, C. (2011). Impact of microfinance on poverty alleviation in Nigeria: An empirical investigation. European Journal of Humanities and Social Sciences, 2(1).

Al-Mubarak, T. (2014). Going 'Beyond Microfinance': Enhancing Islamic Microfinance Programmes in Bangladesh. Islam and Civilisational Renewal (ICR), 5(1), 1-11. https://doi.org/10.12816/0009807

Al-Shami, S. S. A., Majid, I., Mohamad, M. R., \& Rashid, N. (2017). Household welfare and women empowerment through microcredit financing: Evidence from Malaysia microcredit. Journal of Human Behavior in the Social Environment, 27(8), 894-910. https://doi.org/10.1080/10911359.2017.1345341

Ashraf, M. A. (2010). The effectiveness of microcredit programs and prospects of Islamic microfinance institutes (IMFIs) in Muslim countries: A case study of Bangladesh. Journal of Islamic Economics, Banking and Finance, $6(4), 32-45$.

Bangladesh Bureau of Statistics (BBS). (2005). Statistical Yearbook of Bangladesh, BBS, Statistics Division, Ministry of Planning; Govt of Peoples Republic of Bangladesh, Dhaka

Bangladesh Bureau of Statistics (BBS). (2010). Statistical Yearbook of Bangladesh, BBS, Statistics Division, Ministry of Planning; Govt of Peoples Republic of Bangladesh, Dhaka. 
Bangladesh Bureau of Statistics (BBS). (2015). Statistical Yearbook of Bangladesh, BBS, Statistics Division, Ministry of Planning; Govt of Peoples Republic of Bangladesh, Dhaka.

Bangladesh Bureau of Statistics (BBS). (2016). Statistical Yearbook of Bangladesh, BBS, Statistics Division, Ministry of Planning; Govt of Peoples Republic of Bangladesh, Dhaka.

Bashar Bhuiyan, A. (2013). Microcredit and Sustainable Livelihood: An Empirical Study of Islamic and Conventional Credit on the Development of Human Capital of the Borrowers in Bangladesh. Journal of Economic Cooperation \& Development, 34(3).

Begum, H., Alam, A. S. A. F., Mia Md, A., Bhuiyan, F., \& Ghani Ahmad Bashawir, A. (2019). Development of Islamic microfinance: a sustainable poverty reduction approach. Journal of Economic and Administrative Sciences, 35(3), 143-157. https://doi.org/10.1108/JEAS-01-2018-0007

Bhuiyan, A. B., Siwar, C., \& Rashid, M. (2011) b. Islamic Microcredit in Bangladesh. The Global Journal of Finance and Economics, 8(1), 1-21.

Bhuiyan, A. B., Siwar, C., Ismail, A. G., \& Talib, B. A. (2011)a. Financial sustainability \& outreached of MFIs: A comparative study of AIM in Malaysia and RDS of Islami Bank Bangladesh. Australian Journal of Basic and Applied Sciences, 5(9), 610-619.

Boateng, G. O., Boateng, A. A., \& Bampoe, H. S. (2015). Microfinance and poverty reduction in Ghana: Evidence from policy beneficiaries. Review of Business \& Finance Studies, 6(1), 99-108.

Denis, H. (2003). Finance for Growth: Policy Choices in a Volatile World. A World Bank Policy Research Report. In: JSTOR.

Enisan, A. A., \& Oni, I. O. (2012). Impact of microfinance on poverty alleviation in Ondo State, Nigeria. Australian Journal of Business and Management Research, 2(9), 31.

Garikipati, S. (2017). The impact of microfinance on poverty alleviation: making sense of the evidence. In Development Finance (pp. 189-206): Springer. https://doi.org/10.1057/978-1-137-58032-0_7

Ghalib, A. K., Malki, I., \& Imai, K. S. (2015). Microfinance and household poverty reduction: Empirical evidence from rural Pakistan. Oxford Development Studies, 43(1), 84-104. https://doi.org/10.1080/13600818.2014.980228

Halimuzzaman, M., Khaiar, M. A., \& Hoque, M. M. (2014). An analysis of progress of rural development scheme (RDS) by IBBL: A study on Kushtia Branch. Bangla Vision, 13(1), 169-180.

Hassan, A., Hassan, A., Saleem, S., \& Saleem, S. (2017). An Islamic microfinance business model in Bangladesh: Its role in alleviation of poverty and socio-economic well-being of women. Humanomics, 33(1), 15-37. https://doi.org/10.1108/H-08-2016-0066

Idowu, A., \& Oyeleye, O. (2012). Impact of microfinance banks on poverty alleviation in selected local government areas of Oyo state, Nigeria. European Journal of Business and Management, 4(21).

Ifad, I. F. $\quad$ F. $\quad$ A. $\quad$ D. (2019, September 25). Retrieved from https://www.ifad.org/en/web/operations/country/id/bangladesh

ILO. (2016). Bangladesh - Labour Force Survey 2010. Yearly. Switzerland: ILO.

Imai, K. S., \& Azam, M. S. (2012). Does microfinance reduce poverty in Bangladesh? New evidence from household panel data. Journal of Development studies, 48(5), 633-653. https://doi.org/10.1080/00220388.2012.661853

Income, H. (2011). Expenditure Survey (2010). Department of National Planning, Maldives. Retrieved from $\mathrm{http}: / /$ planning. gov. mv

Iqbal, Z., Iqbal, S., \& Mushtaq, M. A. (2015). Impact of microfinance on poverty alleviation: The study of District Bahawal Nagar, Punjab, Pakistan. Management and Administrative Sciences Review, 4(3), 487-503.

Islam, K. A. (2016). Rural Development Scheme: A Case Study on Islami Bank Bangladesh Limited. International Journal of Finance and Banking Research, 2(4), 129. http://doi.org/10.11648/j.ijfbr.20160204.12

Jahan, I., \& Mamun-ur-Rashid, M. (2015). Socio-economic Impact of IBBL Microfinance on Rural Women in a Selected District of Bangladesh. Asian Journal of Agricultural Extension, Economics \& Sociology, 136-148. https://doi.org/10.9734/AJAEES/2015/17356 
Jahur, M. S., \& Quadir, S. N. (2010). Rural development scheme of Islami Bank Bangladesh Limited-A study on its growth, effectiveness and prospect in Bangladesh. Economia: Seria Management, 13(2), 283-299.

Jamal, A. A. N., \& Sheikh, M. A. (2013). Challenges Faced by the Model of Islamic Microfinance for the Development of Micro Entrepreneurs and SMEs in Rural Pakistan. International SAMANM Journal of Finance and Accounting, 1(2), 17-38.

Jinan, T., Bashar, A., Jahan, N., \& Khanam, T. (2008). Impact of Rural Development Scheme of Islami Bank Bangladesh Limited on Beneficiaries in Mymensingh Sadar Area. Progressive Agriculture, 19(2), 205-215. https://doi.org/10.3329/pa.v19i2.16963

Khan, A. A. (2008). Islamic Microfinance. Birmingham, UK: Islamic Relief Worldwide.

Khandker, S. R. (2005). Microfinance and poverty: Evidence using panel data from Bangladesh. The World Bank Economic Review, 19(2), 263-286. https://doi.org/10.1093/wber/lhi008

Kustin, B. (2015). Islamic (Micro) Finance: culture, context, promise, challenges. Seattle, WA: Bill and Melinda Gates Foundation.

Mauri, A., Dell'Amore, G., Masini, M., \& Mottura, P. (1983). Mobilization of household savings: a tool for development (2nd ed.). Milan: Finafrica

Nader, Y. F. (2008). Microcredit and the socio-economic wellbeing of women and their families in Cairo. The Journal of Socio-Economics, 37(2), 644-656. https://doi.org/10.1016/j.socec.2007.10.008

Nawaz, S. (2010). Microfinance and poverty reduction: evidence from a village study in Bangladesh. Journal of Asian and African studies, 45(6), 670-683. https://doi.org/10.1177/0021909610383812

Peters, D. H., Garg, A., Bloom, G., Walker, D. G., Brieger, W. R. \& Hafizur Rahman, M. 2008. Poverty and access to health care in developing countries. Annals of the New York Academy of Sciences, 1136(1), 161-171. http://doi.org/10.1196/annals.1425.011

Rahman, M. M. (2010). Islamic micro-finance program and its impact on rural poverty alleviation. International Journal of Banking and Finance, 7, 119-138.

Rahman, M. M., Jafrullah, M., \& Islam, A. T. (2008). Rural development scheme of Islami Bank Bangladesh Limited (IBBL): assessment and challenges. International Journal of Economics, Management and Accounting, 16(2).

Rashad, D. (2014). New trends in global Islamic Microfinance. Islamic Finance News Supplements, 21-22.

Riwajanti, N. I. (2013). Islamic microfinance as an alternative for poverty alleviation: A survey. Afro Eurasian Studies, 2(1-2), 254-271.

Rokhman, W. (2013). The effect of Islamic microfinance on poverty alleviation: Study in Indonesia. Economic Review: Journal of Economics and Business, 11(2), 21-30.

Rulindo, R., \& Pramanik, A. H. (2013). Finding a way to enhance impact of Islamic microfinance: The role of spiritual and religious enhancement programmes. Developing Country Studies, 3(7), 41-52.

Titumir, R. A. M., \& Rahman, K. M. M. (2011). Poverty and inequality in Bangladesh. Social Policy Unit of Unnayan Onneshan, Dhaka.

UNDP. (2012, November). Scaling up Islamic Microfinance in Bangladesh through the Private Sector: Experience of Islami Bank Bangladesh Limited (IBBL). One United Nations Plaza, New York, NY 10017 USA. Retrieved from www.undp.org/-poverty

Waiganjo, K. S. (2008). Impact of Microfinance Services on Poverty Alleviation at the Household Level. Signature, 61, 70363. 